\title{
Microbiological and Physicochemical Properties of Krakrama (Brackish) Water in Rivers State, Niger Delta, Nigeria
}

\author{
Lawrence 0 Amadi*, Beremboba T Berembo and Samuel A Wemedo \\ Department of Microbiology, Faculty of Science, Rivers State University, \\ Nkpolu-Oroworukwo, Port Harcourt, Nigeria \\ *Corresponding Author: Lawrence O Amadi, Department of Microbiology, Faculty \\ of Science, Rivers State University, Nkpolu-Oroworukwo, Port Harcourt, Nigeria.
}

Received: February 18, 2020
Published: May 04, 2020

(C) All rights are reserved by Lawrence 0 Amadi., et al.

\begin{abstract}
Background: Microbiological and Physicochemical properties of brackish water ecosystem is influenced by a lot of ecological and anthropogenic factors. These factors in turn impact on the distribution, productivity and microbial community as well as the integrity of the ecosystem.

Objective: Assessment of Microbiological and physicochemical properties of Krakrama (brackish) water in Rivers State.

Method: A 2-week sampling protocol at four different points along the brackish water course was carried out for three (May-July) months. Samples were analysed for Microbiological and Physicochemical parameters using standard analytical methods highlighted in the study.

Results: Physicochemical parameters ranged as follows $\mathrm{pH}(6.29-6.71)$, temperature $\left(26.9-28.4^{\circ} \mathrm{C}\right)$, electrical conductivity (EC $950.77-1514.15 \mu \mathrm{S} / \mathrm{cm})$, Nitrate $(0.51-1.34 \mathrm{mg} / \mathrm{mL})$ and salinity $(16.20-22.50 \%)$ values were within statutory permissible limits, but total suspended solids (TSS 28.03-76.17) and total dissolved solids (TDS $570.8-915.30 \mathrm{mg} / \mathrm{mL}$ ) were below whereas turbidity (30.80 - $40.00 \mathrm{NTU}$ ), biochemical oxygen demand (BOD $59.68-15.20 \mathrm{mg} / \mathrm{L})$, Chemical oxygen demand (COD $154.2-214 \mathrm{mg} / \mathrm{mL}$ ), dissolved oxygen (DO $5.19-6.65 \mathrm{mg} / \mathrm{L}$ ) and phosphate exceeded the acceptable limits though most of them do not directly apply to brackish water. In contrast, fifteen (15) genera of bacteria were identified and six (6) genera of fungi. Total heterotrophic bacterial counts (THBCs) ranged from $6.65 \pm 0.1-6.92 \pm 0.1 \times 10^{4} \mathrm{CFU} / \mathrm{mL}$ as highest and least total Shigella-Salmonella counts (TSSCs 3.82 $\pm 0.1 \times 10^{1} \mathrm{CFU} / \mathrm{mL}$ ). Total faecal/thermotolerant coliform bacteria ranged from $900-\geq 1600 / 100 \mathrm{~mL}$ whereas total fungal counts ranged from $2.12 \pm 01-2.28 \pm 0.1 \times 10^{2}$ with Penicillium being predominant. Of the isolates obtained Escherichia coli, Bacillus cereus, Vibrio cholerae, V. parahaemolyticus, Streptococcus pneumoniae, Staphylococcus aureus, Pseudomonas aeruginosa as well as Candida albicans, Fusarium and Aspergillus niger are known aetiologic agents of various human and animal pathologies.

Conclusion: The water samples revealed elevated levels of physicochemical parameters and requires continuous surveillance due to natural and anthropogenic activities. The microbial community is diverse with high incidence of faecal coliforms and opportunistic pathogens rendering the water unfit for recreation and consumption.
\end{abstract}

Keywords: Anthropogenic; Faecal Coliforms; Physicochemical Parameter; Brackish Water; Microbial Community

\section{Introduction}

Water, doubles as a source of life as well as disease when it is polluted due to increased human population, soil erosion, runoff, agricultural waste, atmospheric deposition, municipal and industrial effluents, discharge of sewage and harmful contaminants $[1,2]$. Coastal waters are one of the nation's most important natural resources, valued for their ecological richness as well as for the many human activities they support. The possibility of transboundary transportation with concomitant discharge of pollutants may consequently constitute a public health challenge, thus, determination of water quality and environmental surveillance/ monitoring especially in the Niger Delta is critical. Water quality is a topical global issue, especially as it impacts on humans in terms of water-borne diseases, deterioration and perturbation of the aquatic ecosystem $[3,4]$.

Water quality is described by its physical, chemical and microbiological characteristics. However, microbiological examination of river waters is obligatory for use-related purposes such as potable water production, irrigation and recreation to assess for potential human pathogens. Such analysis requires bioindicators; plants, planktons, animals and microbes to screen the health of the natural ecosystem [5]. Microbes such as coliform bacteria, Escherichia coli, faecal streptococci, enterococci, etc. have been used to assess faecal pollution and deterioration in fresh water sources; lakes, rivers, underground waters and streams [6]. Polluted water is the major rea- 
son for the spread of many endemic diseases like gastroenteritis, skin and eye infections, cholera, tuberculosis, typhoid, diarrhoea, viral hepatitis A and even death. Mortality in children of less than five years due to water related diseases is estimated at 3.4 - 4 million annually in under developed countries $[7,8]$.

Brackish water is mostly found in estuarine areas where seawater mixes with freshwater and refers to water with salinity of $500-17,000 \mathrm{mg} / \mathrm{L}$; conductivity of $1000-80,000 \mu \mathrm{S} / \mathrm{cm}$ and total dissolved solid of $1000-5000 \mathrm{mg} / \mathrm{L}[9,10]$.

The discharges from industrial effluents containing dissolved salts, leachates of saline soils and the runoff of salt deposits such as halite or gypsum present in the sedimentary rocks also increase the amounts of total dissolved salts and thus lead to the formation of brackish water [11].

Due to the strategic significance of brackish water ecosystem in the Niger Delta, extensive research on the microbiological and physicochemical profiles had been well documented [2,6,12]. This ecosystem is the habitat for a wide range of biodiversity including macrofauna/flora and microorganisms [3,13]. Several workers have also reported that, the physicochemical parameters of the habitats are major determinants of the distribution, composition and productivity of microbial communities with salinity being one of the crucial parametric variables $[14,15]$.

The site for this study is Krakrama River in Asari-Toru Local government Area, Rivers State. The rivers is a tidal brackish water ecosystem and this research is the first of its kind in this coastal community. Human activities include fishing, defaecation, lumbering, recreation (canoeing, bathing and swimming), laundering, sabotage to facilities, trafficking in crude oil and refined products and incriminate waste disposal are prevalent where there are human settlements along the coast line. Apparently, these anthropogenic activities have resulted in direct or accidental discharge of organic and inorganic substances which may have impacted negatively into the surrounding water bodies. This study is designed to investigate the microbiological and physicochemical properties of Krakrama (brackish) water as to isolate, identified potential human pathogens and assess the of level of pollution.

\section{Materials and Methods}

Study area

Krakrama is a community situate in Asari Toru Local Government Area in Rivers State, Niger Delta, Nigeria. Krakrama is approximately $17.2 \mathrm{~km}$ from Buguma and $52.1 \mathrm{~km}$ from Port Harcourt the Rivers State capital. The community is located between latitude $4^{\circ} 45^{\prime} 15^{\prime \prime} \mathrm{N}$ and longitude $6^{\circ} 47^{\prime} 0^{\prime \prime} \mathrm{E}$ and it is a tributary of New Calabar River (Figure 1). The study site was selected based on anthropogenic activities such as defaecation (by pier toilet sys-

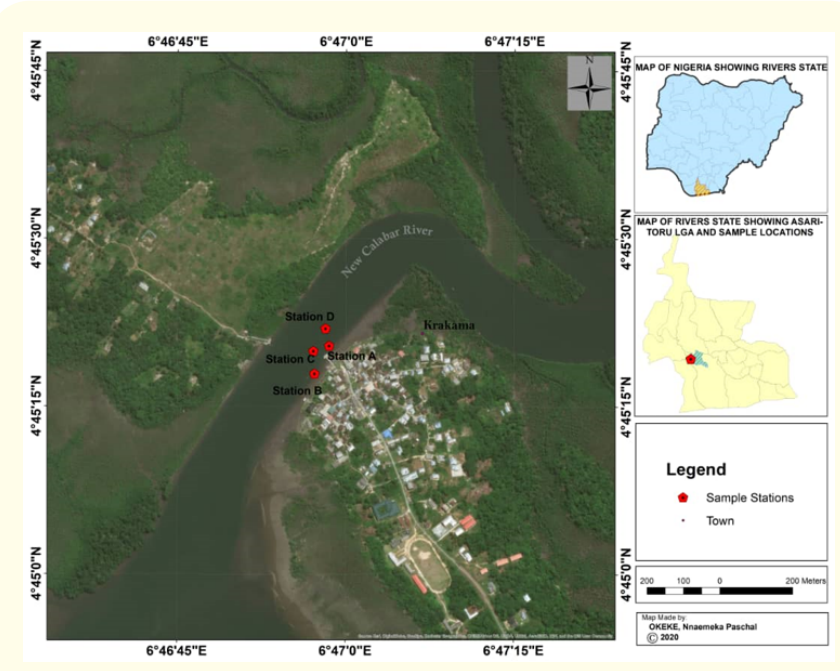

Figure 1: The study site: Krakrama in Asari Toru Local Government Area of Rivers State, Nigeria.

tem), washing, swimming/bathing, lumbering, incriminate disposal of domestic and industrial wastes, etc., into the river.

\section{Collection of water samples}

Brackish water samples from the aforementioned community were collected at four (4) points at about 20 metres away from each other fortnightly for three months (May-July, covering only rainy season). Model bottles used for the water sample collection were labelled and transported in an ice-box for laboratory analyses.

\section{Physicochemical analysis}

Water samples were analysed for the following parameters: Temperatures, pH, Turbidity, Salinity, Dissolved Oxygen (DO), Biochemical Oxygen Demand (BOD), Total suspended solids (TSS), Total dissolved solids (TDS), Electrical conductivity (EC), Phosphates and Nitrates.

\section{pH (Hydrogen ion concentration)}

$\mathrm{pH}$ of the water was measured as described in [16-APHA, 2005] with $\mathrm{pH}$ meter model $291 \mathrm{Mk} 2$ after standardization and calibration with buffered solutions at $\mathrm{pH} 7,4,10$. The $\mathrm{pH}$ meter electrode was lowered into the beaker and the reading was recorded and repeated as required.

\section{Electrical conductivity (EC)}

EC was measured using a standard solution of potassium chloride of known conductivity cell $(0.01 \mathrm{NKCl}, 745.6 \mathrm{mg}$ in $1.0 \mathrm{~L}$ deionized water $=1413 \mu \mathrm{mhos} / \mathrm{cm}$ ) in accordance with [16]. Thus, the conductivity cell/electrode was inserted thrice into $0.01 \mathrm{~N} \mathrm{KCl}$ solution and washed, then conductivity of the solution was measured. Finally, the conductivity cell was immersed into the sample and results were recorded. 
Dissolved oxygen (DO) and biochemical oxygen demand (BOD)

Airtight $300 \mathrm{ml}$ capacity BOD bottles were filled to the brim with the samples. The initial DO in the sample was determined as described [16]. The diluent was prepared by measuring out 22.5 $\mathrm{g} / \mathrm{L} \mathrm{MgSO}_{4} \cdot 7 \mathrm{H}_{2} 0,27.8 \mathrm{~g} / \mathrm{L} \mathrm{CaCl}_{2} \cdot 2 \mathrm{H}_{2} \mathrm{O}$, and $0.25 \mathrm{~g} / \mathrm{L} \mathrm{FeCl} \cdot 6 \mathrm{H}_{2} \mathrm{O}$, Phosphate buffer: $8.5 \mathrm{~g} \mathrm{KHPO}_{4} ; 21.7 \mathrm{~g}$ of $\mathrm{K}_{2} \mathrm{HPO}_{4} \cdot 7 \mathrm{H}_{2} \mathrm{O} ; 1.7 \mathrm{~g}$ of $\mathrm{NaCl}$ and $\mathrm{pH} 7.2$, into a measuring container making up volume to $1 \mathrm{~L}$ with distilled water. The contents of the flask were mixed by swirling gently and covered. The dilution water was first saturated with dissolved oxygen by shaking in a partially filled bottle before using to dilute the samples. BOD bottles were then filled with the diluted samples and another two bottles with the dilution water to serve as blank. The bottles were stoppered carefully to avoid the entrapment of air. The blank and one experimental BOD bottles were used for the initial dissolved oxygen (DO) determination. The remaining two BOD bottles were water-sealed by filling the flared neck of the bottles with distilled water from a wash bottle. The cover cap supplied with the BOD bottles was used to retain the water. The bottles were incubated at $20^{\circ} \mathrm{C}$ for 5 days. At the end of this period, the final DO was determined. The $\mathrm{BOD}_{5} \mathrm{in} \mathrm{mg} / \mathrm{L}$ of the sample was estimated using the formula:

$\mathrm{BOD}_{5}(\mathrm{mg} / \mathrm{L})=\mathrm{D}_{1}-\mathrm{D}_{2} / \mathrm{P}$ ...Equation 1

$\mathrm{D}_{1}=$ Represents Dissolved Oxygen $(\mathrm{mg} / \mathrm{L})$ of sample 15 minutes after preparation.

$\mathrm{D}_{2}=$ Represents Dissolved Oxygen $(\mathrm{mg} / \mathrm{L})$ of sample 5 days after incubation at $20^{\circ} \mathrm{C}$.

$\mathrm{P}=$ Represents Decimal volumetric fraction of sample used.

\section{Chemical oxygen demand (COD)}

This is a measure of oxygen proportion of the untreated matter content of a sample that is susceptible to oxidation by a strong chemical oxidant [17]. A $50 \mathrm{ml}$ brackish water sample was collected in clean glass bottles and dispensed into $500 \mathrm{ml}$ Erlenmeyer flask with 24/40 ground glass joint. Clean boiling clips were added to prevent bumping, $5 \mathrm{ml}$ of sulphuric acid and $1.0 \mathrm{~g}$ of mercuric sulphate were added to the flask. The solution was mixed to dissolve while cooling by immersing in ice water and $25 \mathrm{ml}$ of standard potassium dichromate $(0.25 \mathrm{~N})$ added to it from a $50 \mathrm{ml} \mathrm{bu}-$ rette. The flask was then connected to the condenser and cooling water turned on again. $70 \mathrm{ml}$ of sulphuric acid were slowly added to the flask through the open end of the condenser. The flask was thoroughly mixed by swirling as the sulphuric acid was being added. The hot plate was brought into positions and turned on. The temperature was adjusted to allow the refluxing liquid to rise at least half the height of the condenser. Foreign materials were kept away by placing a beaker at top end of the condenser. Refluxing was carried out for 2 hours, after which the flask was allowed to cool. The condenser was washed down with distilled water using a wash bottle. The content of the flask was made up to $300 \mathrm{ml}$ with distilled water and allowed to cool to room temperature. About 3 drops of ferroin indicator were added to the flask. The excess potassium dichromate was titrated with standard ferrous ammonium sulphate $(0.1 \mathrm{~N})$, to the first appearance of the reddish-brown colour end-point. The volume of the titrant was taken at the end. The COD in $\mathrm{mg} / \mathrm{L}$ was estimated as follows:

$C O D \backslash(m g / L)=(A-B) N x \backslash 8000 / S$. Equation 2

$A=$ Represents $\mathrm{ml}$ of titrant used for the blank

$\mathrm{B}=$ Represents $\mathrm{ml}$ of titrant used for the sample

$\mathrm{N}=$ Represents Normality of titrant

$\mathrm{S}=$ Represents $\mathrm{ml}$ of sample used for the test.

\section{Turbidity}

Turbidity affects light penetration, scattering and absorption in the aquatic environment and it is measured with a standard Formazin polymer as a reference to compare intensity of light scattered by the sample. Distilled water was used to calibrate nephelometer (0.0 NTU). Hydrazine sulphate $1.0 \mathrm{~g}$ was dissolved in 100 $\mathrm{ml}$ of distilled water to form solution 1 . Hexamethylenetetramine $10.0 \mathrm{~g}$ was dissolved in distilled water and made up to $100 \mathrm{ml}$ in volumetric flask to obtain solution 2 . Then $5 \mathrm{ml}$ of solutions 1 and 2 were mixed in a volumetric flask and kept for $24 \mathrm{~h}$ at about $25^{\circ} \mathrm{C}$. The mixture was diluted to $1000 \mathrm{ml}$ with distilled water to give a 400 NTU stock suspension. Afterwards, $10 \mathrm{ml}$ of the stock solution was diluted to $100 \mathrm{ml}$ with distilled water to give 40NTU standard solution [16]. Turbidity was calculated using the formula below:

Turbidity $($ NTU) $=$ Nephelometer readings $x$ Dilution factor. Equation 3

If turbidity of the sample is $>40 \mathrm{NTU}$, then the sample is diluted and the dilution factor is accounted for in final calculations.

\section{Total suspended solids}

This parameter for the water sample was determined as described in [16]. Vacuum pump with distilled water was applied to wash the membrane filter (pore size $0.45 \mu \mathrm{m}$ ). The membrane filter was carefully separated, placed in the crucible and dried in the oven at $103^{\circ} \mathrm{C}$ for $1 \mathrm{~h}$. During the analysis, the dried filter paper was wetted with a small volume of distilled water and placed in the filtration unit. About $50 \mathrm{ml}$ of homogenously mixed test sample was filtered through the membrane, the contents with membrane filter was transferred to the crucible and oven dried to a constant weight at $103^{\circ} \mathrm{C}$. 
Total dissolved solids

These are solids that is regularly dissolved in water making it unhealthy for consumption. It is calculated by subtracting weight of total suspended solids from total solids as represented in equation 7.

Total Dissolved Solids $\left(\frac{m g}{L}\right)=\left(\left(\mathrm{W}_{1}-\mathrm{W}_{2}\right)\right) \times 1000 \ldots \ldots \ldots .$. Equation 4

Where: $\mathrm{W}_{1}$ represents Weight of total solids.

$\mathrm{W}_{2}$ represents Weight of total suspended solids.

Temperature

Temperature of the water sample was measured at the sampled site immediately after collection using mercury in glass thermometer graduated in centigrade $\left({ }^{\circ} \mathrm{C}\right)$. The thermometer remained immersed for 5 minutes to stabilize and the thermometric readings was recorded

\section{Salinity}

The salinity of the water sample was measured in the laboratory as described in Horiba Instruction Manual [18]. About $20 \mathrm{ml}$ of water was dispensed into a beaker and the salinity was read by immersion of the probe after standardization for about 3-minutes.

\section{Phosphate}

A simple qualitative method was used to determine the presence of phosphate ions in the water sample. A small amount of the sample was acidified with concentrated nitric acid, to which a little ammonium molybdate was added. The presence of phosphate ions was indicated by the formation of a bright yellow precipitate layer of ammonium phosphomolybdate. The appearance of the precipitate can be facilitated by gentle heating. This test is also used to detect arsenic, a yellow precipitate being formed.

\section{Nitrate}

The brown ring test was performed by adding iron (II) sulphate to the water sample containing nitrate, then slowly concentrated sulphuric acid was added such that the acid forms a layer below the aqueous solution. A brown ring will form at the interface of the two layers, indicating the presence of the nitrate ion. The overall reaction is the reduction of the nitrate ion by iron (II) which is oxidized to iron (III) and formation of a nitrosonium complex where nitric oxide is reduced to $\mathrm{NO}^{-}$(nitrite).

$$
\begin{aligned}
& 2 \mathrm{HNO}_{3}+3 \mathrm{H}_{2} \mathrm{SO}_{4}+6 \mathrm{FeSO}_{4} \longrightarrow 3 \mathrm{Fe}_{2}\left(\mathrm{SO}_{4}\right)_{3}+2 \mathrm{NO}+4 \mathrm{H}_{2} \mathrm{O} \\
& {\left[\mathrm{Fe}\left(\mathrm{H}_{2} \mathrm{O}\right)_{6}\right] \mathrm{SO}_{4}+\mathrm{NO}=\left[\mathrm{Fe}\left(\mathrm{H}_{2} \mathrm{O}\right)_{5}(\mathrm{NO})\right] \mathrm{SO}_{4}+\mathrm{H}_{2} \mathrm{O}}
\end{aligned}
$$

This test is sensitive up to $2.5 \mu \mathrm{g}$ and a concentration of 1 in $25,000 \mathrm{ppm}$.

\section{Microbiological analysis}

Total heterotrophic bacterial count (THBC) were determined when serial dilutions were made from the samples and 0.1 aliquots were spread-plated in duplicate on nutrient agar (NA; Titan Biotech Ltd, India). Total coliforms including Escherichia coli count (TCC) were determined on pre-poured, surface-dried MacConkey agar (Oxoid Ltd., UK) and incubated for $37^{\circ} \mathrm{C}$ for $24 \mathrm{~h}$. Total faecal coliform count (TFCC) was obtained from $1 \mathrm{ml}$ of dilution $10^{1}$ of sample inoculated on surface-dried Eosin Methylene Blue Agar at $44.5^{\circ} \mathrm{C}$ for $24 \mathrm{~h}$. Most probable number technique (MPN) was also performed using fifteen (15) test tubes for each sample of $10 \mathrm{ml}, 1$ $\mathrm{ml}$ and $0.1 \mathrm{ml}$ with double or single strength $[17,19]$. Total Shigella and Salmonella Count (TSSC) was determined on pre-poured Shigella-Salmonella agar whereas total Vibrio count (TVC) was determined in duplicates on surface-dried thiosulphate-citrate bile-saltsucrose (TCBS) agar (Lab M Ltd, UK) using spread-plate method and plates were incubated at $37^{\circ} \mathrm{C}$ for $24 \mathrm{~h}$. Representative colonies (30 - 300) were enumerated as colony forming units (CFUs) and identification of bacterial isolates was carried out based on cultural, morphological and biochemical characteristics [20-22] and ABI identification software.

Total fungal count (TFC) was determined with $0.1 \mathrm{ml}$ aliquots of decimal dilutions and inoculated onto prepoured solidified Sabouraud's dextrose agar (SDA; Titan Biotech Ltd, India) and incubated at $27 \pm 2^{\circ} \mathrm{C}$ for 1 - 4 days. Viable representative colonies were picked at random, streaked and subcultured for purification and stored in the refrigerator at $2-4^{\circ} \mathrm{C}$. Then, isolates were identified after staining with lactophenol cotton blue and compared with observed cultural and morphological characteristics as described $[22,23]$.

\section{Statistical analysis}

The analyses were carried out after two and six determinations and means calculated manually. ANOVA used was based on software of SPSS version 22 for Windows and the significance of the mean differences determined at $\mathrm{p}<0.05$.

\section{Results}

Physicochemical parameters of Krakrama River at different points of assessment are presented in table 1 . The mean $\mathrm{pH}$ values of the water samples at different points ranged from 6.29 - 6.71, with sample $A$ as the highest and $D$ least. Temperature mean values ranged from $26.9-28.4^{\circ} \mathrm{C}$, with samples at points $\mathrm{A}$ and $\mathrm{D}$ being the highest and B lowest. DO mean values ranged from 6.65 - 5.19 $\mathrm{mg} / \mathrm{L}$, the highest being sample A, and B lowest. Mean BOD values ranged from $9.68-15.20 \mathrm{mg} / \mathrm{mL}$ the highest occurred at sampled point $\mathrm{C}$ and lowest at D. COD mean values ranged from 154.23 $214.41 \mathrm{mg} / \mathrm{mL}$, highest at point B and lowest at D. Salinity mean 


\begin{tabular}{|c|c|c|c|c|c|c|}
\hline \multicolumn{7}{|c|}{ Permissible limit of: } \\
\hline Parameter & Point A & Point B & Point C & Point D & USEPA & WHO \\
\hline $\mathrm{pH}$ & 6.71 & 6.58 & 6.37 & 6.29 & $6.5-8.5$ & \\
\hline Temperature & 28.4 & 26.9 & 28.3 & 28.4 & 40.0 & $20.0-30.0$ \\
\hline DO (mg/L) & 6.65 & 5.19 & 5.83 & 5.41 & $40.0-60.0$ & $\geq 5.0$ \\
\hline BODs (mg/L) & 13.52 & 10.82 & 15.20 & 9.68 & 10.0 & $2.0-6.0$ \\
\hline COD (mg/L) & 177.09 & 214.41 & 197.98 & 154.23 & & 7.5 \\
\hline Salinity (\%/ppt) & 22.50 & 17.00 & 16.50 & 16.20 & NA & \\
\hline EC ( $\boldsymbol{\mu S} / \mathrm{cm})$ & 1514.15 & 950.77 & 1125.53 & 989.90 & 400.0 & 600.0 \\
\hline Turbidity (NTU) & 40.00 & 39.50 & 30.80 & 32.50 & 5.10 & 5.0 \\
\hline TSS (mg/L) & 45.57 & 28.03 & 76.17 & 54.10 & & 500.0 \\
\hline TDS (mg/L) & 915.30 & 570.84 & 673.74 & 897.19 & 2000.0 & $500.0-1000.0$ \\
\hline Phosphates & 3.89 & 9.60 & 5.45 & 4.96 & & \\
\hline Nitrate (mg/L) & 1.34 & 1.08 & 0.51 & 1.02 & & 5.00 \\
\hline
\end{tabular}

Table 1: Physico-chemical parameters of Krakrama River at different sample collection.

Legend: WHO: World Health Organisation, 2011; (USEPA): United States Environmental Protection Agency, 2000; Values are means of duplicates. NA = Not applicable.

values ranged from 16.20 - $22.50 \mathrm{ppt}$, highest value was observed at point $A$ and lowest at D. Mean EC levels was between 950.77 and $1514.15 \mu \mathrm{S} / \mathrm{cm}$ with sampled point A being the highest and B lowest. Turbidity mean values ranged from 30.80 - 40.00 NTU, highest value was observed at point B and least C. Mean TSS ranged from $28.03-76.17 \mathrm{mg} / \mathrm{L}$, highest value occurred at point $\mathrm{C}$ and lowest at B. Mean TDS level ranged from $570.84-915.30 \mathrm{mg} / \mathrm{L}$, highest was observed at point $A$ and lowest at B. Mean phosphate values ranged from $3.89-9.60 \mathrm{mg} / \mathrm{L}$, the highest being at sampled $B$ and least at A. Mean nitrate level ranged from $0.51-1.34 \mathrm{mg} / \mathrm{L}$, sampled point $\mathrm{A}$ had the highest whereas the lowest occurred at sampled point C. However, fluctuations in these parameters are not unconnected with anthropogenic activities.

Microbial group counts for THBC, TCC, TFCC, TVC, TSSC and TFC of samples from different points in Krakrama River are shown in table 2. THBC mean values ranged from $6.65 \pm 0.13-6.92 \pm 0.08$ $\mathrm{x} 10^{4} \mathrm{CFU} / \mathrm{mL}$ at point $\mathrm{A}$ which had the highest and point $\mathrm{B}$, lowest. Mean level of TCC ranged from $3.98 \pm 0.10-4.26 \pm 0.33 \times 10^{1}$ with sample at point $\mathrm{A}$ being the highest and point $\mathrm{C}$ the least. TFCC mean values ranged from $3.88 \pm 0.09-4.14 \pm 0.38 \times 10^{1}$, highest mean value occurred at point $B$ and point $D$ being the lowest. TVC mean values was between $3.89 \pm 0.06$ and $4.04 \pm 0.00 \times 10^{1}$ with highest mean value at sampled point $A$, the lowest being at point D. Mean values of TSSC ranged from $3.82 \pm 0.09-4.07 \pm 0.09 \times 10^{1}$ highest mean value occurred at point $A$ and lowest at $C$. Total fungal count (TFC) mean values ranged from $2.12 \pm 0.05-2.28 \pm 0.05 \mathrm{x}$ $10^{2}$, sampled point $A$ had the highest whereas point $\mathrm{D}$ least.

TFCCs of water from the sampled points (A-D) using the Most Probable Number (MPN) method are depicted in table 3. Counts ranged from $900-\geq 1600$. Sampled points A and B had higher counts than points $\mathrm{C}$ and $\mathrm{D}$ (Table 3 ).

Microbial isolates of water from the sampled points were fifteen (15) genera of bacteria and six (6) of fungi table 4 and 5. Percentage occurrence of identified bacteria at the different sampled points are highlighted in table 4. Point $\mathrm{A}$ had the highest bacterial load and

\begin{tabular}{|c|c|c|c|c|c|c|}
\hline Points & THBC $\left.\left(\mathrm{x}^{10}\right)^{4}\right)$ & $\operatorname{TCC}\left(\mathbf{x 1 0}^{1}\right)$ & TFCC $\left(\times 10^{1}\right)$ & $\operatorname{TVC}\left(\mathrm{x}^{1} 0^{1}\right)$ & TSSC $\left(\mathrm{x}^{10^{1}}\right)$ & $\operatorname{TFC}\left(\mathrm{x}^{-2}\right)$ \\
\hline $\mathrm{A}$ & $6.92 \pm 0.08^{c}$ & $4.26 \pm 0.33^{\mathrm{b}}$ & $4.05 \pm 0.17^{\mathrm{ab}}$ & $4.04 \pm 0.00^{\mathrm{b}}$ & $4.07 \pm 0.09^{b}$ & $2.28 \pm 0.05^{\mathrm{a}}$ \\
\hline B & $6.81 \pm 0.09^{b c}$ & $4.06 \pm 0.05^{\mathrm{ab}}$ & $4.14 \pm 0.38^{\mathrm{a}}$ & $3.98 \pm 0.05^{\mathrm{ab}}$ & $4.01 \pm 0.09^{\mathrm{b}}$ & $2.22 \pm 0.05^{\mathrm{a}}$ \\
\hline $\mathrm{C}$ & $6.74 \pm 0.16^{\mathrm{a}}$ & $3.98 \pm 0.10^{\mathrm{a}}$ & $3.93 \pm 0.16^{\mathrm{a}}$ & $3.92 \pm 0.11^{\mathrm{a}}$ & $3.87 \pm 0.09^{\mathrm{a}}$ & $2.13 \pm 0.06^{\mathrm{a}}$ \\
\hline $\mathrm{D}$ & $6.65 \pm 0.13^{\mathrm{a}}$ & $3.99 \pm 0.04^{a}$ & $3.88 \pm 0.09^{\mathrm{a}}$ & $3.89 \pm 0.06^{\mathrm{a}}$ & $3.82 \pm 0.09^{\mathrm{a}}$ & $2.12 \pm 0.05^{\mathrm{a}}$ \\
\hline
\end{tabular}

Table 2: Microbial group counts (CFU/mL) of water at different sampled points.

Legend: a,band $\mathrm{c}$ : Means of values with the same superscript (alphabet) across the column. Shows no significant difference at ( $p>0.05$ ). Values are means of duplicates \pm standard deviation (SD) of the mean. TCC $=10 / 100 \mathrm{~mL}$ and THBC $=100000 / \mathrm{mL}$ WHO, 2011 . 


\begin{tabular}{|c|c|c|c|c|}
\hline \multirow{2}{*}{$\begin{array}{c}\text { Points/Duration Index/100mL } \\
\text { 2-Weeks }\end{array}$} & \multicolumn{3}{|c|}{ Dilutions (mL)/Number of Positive Tubes } & \multirow[t]{2}{*}{ MPN } \\
\hline & 5 of $10 \mathrm{~mL}$ each & 5 of $1 \mathrm{~mL}$ each & 5 of $0.1 \mathrm{~mL}$ each & \\
\hline A (Toilet/defaecation $\left.{ }^{+}\right)$ & 5 & 5 & 5 & $\geq 1600$ \\
\hline B (Domestic waste ${ }^{+}$) & 5 & 5 & 5 & $\geq 1600$ \\
\hline C (Bathing $)$ & 5 & 5 & 3 & 900 \\
\hline D (Bathing/Washing $\left.{ }^{+}\right)$ & 5 & 5 & 3 & 900 \\
\hline
\end{tabular}

Table 3: Estimation of TFCC by MPN for various combinations of Positive and Negative Results with five $10.0 \mathrm{~mL}$ portions, five $1.0 \mathrm{~mL}$ portions and five $0.1 \mathrm{~mL}$ portions.

Legend: ': Anthropogenic activities at various sampled points (A-D) in Krakrama river. Value represents mean of six determinations.

\begin{tabular}{|l|c|c|c|c|}
\hline \multicolumn{1}{|c|}{ Isolates } & A & B & C & D \\
\hline Bacillus cereus & 1.25 & 0 & 1.25 & 0 \\
\hline B. subtilis & 1.25 & 1.25 & 0 & 0 \\
\hline B. siamensis & 1.25 & 1.25 & 1.25 & 0 \\
\hline B. tequilensis & 0 & 1.25 & 1.25 & 0 \\
\hline B. niacin & 0 & 1.25 & 1.25 & 1.25 \\
\hline Bifobacterium bifidum & 1.25 & 1.25 & 1.25 & 0 \\
\hline Citrobacter freundii & 1.25 & 1.25 & 0 & 1.25 \\
\hline C. koseri & 1.25 & 1.25 & 0 & 0 \\
\hline Corynebacterium xerosis & 1.25 & 1.25 & 0 & 0 \\
\hline Escherichia coli & 2.50 & 2.50 & 1.25 & 1.25 \\
\hline Enterobacter clocae & 1.25 & 1.25 & 0 & 0 \\
\hline Klebsiella pneumoniae & 1.25 & 1.25 & 1.25 & 0 \\
\hline K. aerogenes & 0 & 0 & 1.25 & 1.25 \\
\hline K. oxytoca & 1.25 & 1.25 & 0 & 0 \\
\hline K. singaporensis & 1.25 & 0 & 1.25 & 0 \\
\hline Proteus mirabilis & 1.25 & 0 & 0 & 1.25 \\
\hline P. vulgaris & 1.25 & 1.25 & 0 & 0 \\
\hline Providencia regretti & 1.25 & 1.25 & 0 & 0 \\
\hline Pseudomonas aeruginosa & 2.50 & 2.50 & 1.25 & 1.25 \\
\hline Serratia marcescens & 1.25 & 1.25 & 0 & 0 \\
\hline S. odorifera & 1.25 & 1.25 & 0 & 0 \\
\hline Shigella flexneri & 1.25 & 0 & 1.25 & 1.25 \\
\hline Shewanella putrefaciens & 1.25 & 0 & 0 & 0 \\
\hline Staphylococcus aureus & 1.25 & 1.25 & 0 & 1.25 \\
\hline S. deverisei & 1.25 & 1.25 & 0 & 0 \\
\hline S. epidermidis & 1.25 & 0 & 1.25 & 1.25 \\
\hline Streptococcus pneumoniae & 1.25 & 0 & 0 & 0 \\
\hline Vibrio cholerae & 1.25 & 1.25 & 0 & 0 \\
\hline V. parahaemolyticus & 1.25 & 0 & 0 & 1.25 \\
\hline V. aerogenes & 1.25 & 0 & 1.25 & 0 \\
\hline V. alginolyticus & 1.25 & 0 & 0 \\
\hline V. fluvialis & 0 & 0 & 0 \\
\hline V. metschnikovii & & & 0 \\
\hline
\end{tabular}

diversity/heterogeneity followed by point $B$ and the lowest at point D. The predominant single species were Escherichia coli and Pseudomonas aeruginosa obtained at sampled points A and B whereas the most predominant genera on the basis of diversity were $\mathrm{Ba}$ cillus (15\%) and Vibrio (13.7\%) followed by Staphylococcus (10\%) and Klebsiella (7.5\%) (Table 4).

Percentage occurrence of identified fungi from different sampled points are highlighted in table 5 . Sampled points A and C had

\begin{tabular}{|l|c|c|c|c|}
\hline \multicolumn{1}{|c|}{ Isolates } & A & B & C & D \\
\hline Penicillium chrysogenum & 4.0 & 4.0 & 4.0 & 4.0 \\
\hline P. italicum & 4.0 & 4.0 & 4.0 & 4.0 \\
\hline Aspergillus niger & 4.0 & 4.0 & 4.0 & 4.0 \\
\hline Fusarium solani & 4.0 & 4.0 & 4.0 & 4.0 \\
\hline Mucor spp. & 4.0 & 4.0 & 4.0 & 0 \\
\hline Candida albicans & 4.0 & 0 & 4.0 & 4.0 \\
\hline Saccharomyces cerevisiae & 4.0 & 4.0 & 4.0 & 0 \\
\hline
\end{tabular}

Table 5: Percentage occurrence of fungal isolates from each Sampled points (A-D) from Krakrama River

the highest fungal load and diversity with Penicillium being the most dominant genera.

\section{Discussion}

Physicochemical and microbiological characteristics of brackish water systems are driven by several environmental and human activities. In this water system, intense biogeochemical transformations cause pronounced $\mathrm{pH}$ fluctuations due to the uptake of anthropogenic emissions and high loads of dissolved organic matter [24]. The mean $\mathrm{pH}$ values recorded were near neutral and varied at sampled points. Such variations in $\mathrm{pH}$ at very small distances have been reported to be linked to atmospheric and anthropogenic emissions (defaecation, disposal of domestic wastes, etc), buffering and dilution effects of heavy rains. This acidic-alkaline $\mathrm{pH}$ of the brackish water may not only relief physiological stress but best suited to support aquatic life, and corroborates earlier reports $[3,25,26]$.

Table 4: Percentage occurrence of bacterial isolates in water from the Sampled points (A-D). 
The temperature drives the biochemical and chemical reactions of water system and impacts on the rate of all biological activities. Therefore, it can be used as an initial step to predict the effects of human activities on aquatic lives [1]. The mean temperature results ranged from $26.9-28.4^{\circ} \mathrm{C}$ which is within statutory permissible limit. Slight fluctuations were observed at sampled points which may be attributed to insulating effects of increased nutrient load, evaporation, fresh water influx and anthropogenic inputs which is in consonance with those reported by other investigators $[2,27]$.

Dissolved oxygen (DO) is a fundamental factor for metabolism of the aerobic aquatic organisms, determines natural depuration capacity or freshness of a river [28]. Although, mean DO values were slightly above the threshold limits for drinking water as recommended [7] higher concentrations have been reportedly used agricultural purposes in brackish water aquaculture [29].

Both $\mathrm{BOD}_{5}$ and COD are key indicators of the environmental health of a surface water supply, they are rarely in general water treatment [1]. Mean BOD values of all the sampled points exceeded recommended maximum permissible limits of $2-6.0 \mathrm{mg} / \mathrm{mL}$ [9] obviously due to discharge of domestic wastes (sewage) and poorly executed agricultural activities near the river banks. The impact of these activities may result in the accumulation of suspended particulate matter with insulation effect on the estuary and such seasonal ranges had earlier been reported $[12,30]$. Unpolluted waters typically have values of $2 \mathrm{mg} / \mathrm{L}$ or less, whereas those receiving wastewaters may have values up to $10 \mathrm{mg} / \mathrm{L}$ or more.

COD is another measure of organic material contamination, the amount of dissolved oxygen required to cause chemical oxidation of the organic material in water. Mean COD values ranged from $154.23-214.0 \mathrm{mg} / \mathrm{L}$ indicative of the presence of decaying organic matter and inorganic pollutants respectively. This range fell within the purview of polluted waters $20-200 \mathrm{mg} / \mathrm{L} \mathrm{[25]} \mathrm{which} \mathrm{may} \mathrm{be}$ associated with the discharge of untreated or incompletely treated industrial effluents, run-off, microbial activity and domestic wastes into the river as earlier reported [31].

Seasonality of salinity in the New Calabar River are driven by rainfall regime, tidal cycle, soil erosion, dilution effect, anthropogenic and ecological factors which may result in changes in the ratios of main phylogenetic groups: Archaea, Bacteria, Algae and Cyanobacteria [14]. Salinity values were within the range recorded for growth and best sustainability of brackish water aquaculture $[15,26]$. Despite the frequency of fluctuations in salinity there should be monitoring and control of the water environments to safe and sustain aquatic life forms.
EC and TDS are frequently used as water quality parameters, especially in the coastal area and these parameters are indicators of salinity level which makes them very useful in studying seawater intrusion [32]. Mean EC values suggest addition of dissolved solids from atmospheric and anthropogenic emissions as well as erosion activities which corroborate reports of other workers on related water bodies $[4,6,33]$. EC in water is due to ionization of dissolved inorganic solids and becomes a measure of total dissolved solids. It is used as a primary index to select the suitability of water for all purposes [34].

The TSS reported in the study were below permissible limit [9] whereas TDS was near maximum, accentuated by the location of open toilet facility, domestic waste and suspended materials discharged at points A and D. The occurrence of such levels of TSS and TDS in recent times have been reported in literatures [35,36] with evidence of survival of aquatic biota.

High turbidity water has an altered odour, taste and negatively impacts the aesthetic values as well as light penetration into the water column necessary for survival and sustainability of aquatic life. High mean turbidity values obtained during the study may be attributed to the effects of torrential rains, wind and increased flow velocity with more suspended particles from sewage wastes, surface runoff and soil erosion. The turbidity values were astronomically higher than that stipulated for domestic use [9].

Increasing loads of nitrogen $(\mathrm{N})$ and phosphorus $(\mathrm{P})$ in water bodies has become one of the major environmental problems facing the world. Nitrates indicate the presence of fully oxidized organic matter. The mean nitrate values were lower than the permissible limit earlier reported $[7,37]$ which implies that the analysed water samples contained low levels of oxidized organic matter. Although, nitrates are relatively non-toxic at the concentration recorded, in excess, they may result in eutrophication and impede overall survival and growth of plants and cause methemoglobinemia in infants, i.e. blue baby syndrome $[8,38,39]$. In contrast, phosphate in two sampled points (B and C) exceeded the WHO permissible limit for drinking water whereas points $A$ and $D$ within the limit. Phosphorus is an essential element for all life and an integral part of the DNA molecule. But in excess phosphorous stimulates algal growth which can endanger other aquatic lives. However, phosphate pollution levels at sampled points may be attributed to geologic weathering, phosphate detergent, fertilizer application and animal wastes, rainfall patterns as well as anthropogenic impacts which concurs with $[40,41]$. Since Nigeria has no regulation criterion for phosphates, concentrations tend to always exceeded maximum contaminant levels (MCLs) of foreign regulation agencies such as Swaziland Water Service Corporation (SWSC) - i.e. $1.0 \mathrm{mg} / \mathrm{L}$ 
for drinking water, $2.0 \mathrm{mg} / \mathrm{L}$ for rivers and industrial effluents; South African criterion of $1.0 \mathrm{mg} / \mathrm{L} \mathrm{PO}_{4}$-P for sewage effluents and Zimbabwe Water (Waste and Effluent Disposal) Regulation $[39,42]$ so, emergency control measures are required to avoid hyper-eutrophication.

The diversity of microbial groups observed in the sampled points (Table 4 and 5) may have been favoured by the interplay of the various ecological factors and anthropogenic activities. Such plethora of microorganisms have also been reported by other workers $[3,13,43]$. THBC were slightly below statutory criterion but TCC and TFCC (Table 2) exceeded acceptable limits [9]. Such high E. coli and coliform load may be linked to open defaecation, soil erosion, discharge of industrial and domestic wastes, bathing/washing and recreational activities, thus resulting in proliferation of waterborne pathogens as earlier reported in different rivers $[44,45]$. The absence of Salmonella species however, may be due to the prevailing tropical temperature and level of salinity in brackish habitat. With respect to the various sampled points, the means of TCC (Table 2) at sampled point A was significantly different ( $p>0.05$ ), the elevated faecal coliform counts (Tables 3 ) further validates obvious waterborne faecal pollution as commonly reported in developing countries $[45,46]$. On the other hand, the relatively high total fungal count/load (TFC) observed in this study apart from factors such as human activities, may be attributed to their physiological and morphological adaptation to this habitat. However, water with such magnitude of microbial pathogen contamination including B. cereus, K. pneumonia, Staphylococcus aureus, Streptococcus pneumoniae, $P$. aeruginosa, V. cholerae, V. parahaemolyticus, $C$. albicans, Fusarium and A. niger) poses a serious threat to public health, is unfit for domestic use and consumption and incommodious for recreation.

\section{Conclusion}

This study demonstrates that Krakrama water was impacted by a variety of physicochemical and anthropogenic factors which may become a prolific source of microbial diversity. Elevated levels of total faecal coliforms and pathogenic microflora of public health significance highlights the magnitude of the problem of contamination. However, most of the physicochemical parametric values were within the permissible limit but BOD, COD and phosphate concentrations require emergency intervention measures so that the water would not pose only ecological and socio-economic problems but a threat to public health.

\section{Bibliography}

1. Patil PN., et al. "Physico-chemical parameters for testing of water - A review". International Journal of Environmental Sciences 3.3 (2012): 1194-1207.

2. Onojake MC., et al. "Surface water characteristics and trace metals level of the Bonny/New Calabar River Estuary, Niger Delta, Nigeria". Applied Water Science 7 (2017): 951-959.

3. Amadi LO and Efiuvwevwere BJO. "Seasonal variations in physico-chemical and bacteriological parameters of Ogodogbo creek, Niger Delta Nigeria". International Journal of Environment and Bioenergy 10.2 (2015): 94-106.

4. Titilawo Y., et al. "Physicochemical properties and Total Coliform Distribution of Selected Rivers in Osun State, South western Nigeria". Polish Journal of Environmental Studies 28. 6 (2019): 4417-4428.

5. Parmar TK., et al. "Bioindicators: the natural indicator of environmental pollution". Frontiers in Life Science 9.2 (2016): 110-118.

6. Edokpayi JN., et al. "Evaluation of Microbiological and Physicochemical Parameters of Alternative Source of Drinking Water: A Case Study of Nzhelele River, South Africa". The Open Microbiology Journal 12 (2018): 18-27.

7. World Health Organization. "Guidelines for safe recreational water environments: Coastal and fresh waters". World Health Organization (2004): 1 .

8. Omonigho SE., et al. "Microbiological and Physicochemical Analysis of Orogodo River, Agbor, Delta State, Nigeria". International Journal of Ecological Science and Environmental Engineering 5.2 (2018): 34-42.

9. World Health Organization (WHO). "Guidelines for drinkingwater quality, fourth edition. Recommendations”. WHO Press Geneva Switzerland 1 (2011).

10. Nthunya LN., et al. "Spectroscopic Determination of Water Salinity in Brackish Surface Water in Nandoni Dam, at Vhembe District, Limpopo Province, South Africa". Water 10. 990 (2018): 1-13.

11. Cucci G., et al. "Leaching effect of rainfall on soil under fouryear saline water irrigation". Soil and Water Research 11 (2016): 181-189.

12. Efiuvwevwere BJO and Amadi LO. "Effects of Preservatives on the Bacteriological, chemical and sensory qualities of mangrove oyster (Crassostrea gasar) harvested from the Niger Delta Region, Nigeria". British Journal of Applied Science and Technology 5.1 (2015): 76-84. 
13. Woke GN and Umesi N. "Comparative Study of Sediments Samples from Brackish and Fresh Water in the Lower Niger Delta, Nigeria". International Journal of Research in Agriculture and Forestry 5.5 (2018): 1-7.

14. Bryanskaya AV., et al. "The role of environmental factors for the composition of microbial communities of saline lakes in the Novosibirsk region (Russia)". BMC Microbiology 16.1.4 (2016): 1-14.

15. Veerendra kumar M., et al. "Physico-chemical parameters and bacterial abundance in coastal water of Visakhapatnam, Bay of Bengal India, with special reference to Pseudomonas sp. and Vibrio sp". Indian Journal of Geo Marine Sciences 46. 08 (2017): 1588-1595.

16. American Public Health Association (APHA). "Standard methods for Examination of water and wastewater". $21^{\text {st }}$ Edition, APHA, Washington D.C. (2005).

17. APHA. "Standard Methods for the examination of water and wastewater". $19^{\text {th }}$ edition, American Public Health Association, Washington DC (1992).

18. Horiba Instruction Manual. "Water Quality checker U-10". $2^{\text {nd }}$ edition. Tokyo, Japan (1991): 54-67.

19. Tortora GJ., et al. "Microbiology; An Introduction". $5^{\text {th }}$ edition. The Benjamin/Cummings Publishing Company, Inc. 390 Bridge Parkway, USA 723 (1995): 159-161.

20. Harrigan EF and McCane ME. "Laboratory Methods in Food and Diary Microbiology". Academic Press London 5 (1990).

21. Sneath PHA., et al. "Bergey's Manual of Systemic Bacteriology". Williams and Wilkins, Baltimore, MD, USA. 2 (1986).

22. Forbes BA., et al., "Bailey and Scott's Diagnostic Microbiology". International edition. $12^{\text {th }}$ edition. Mosby, Inc., an affiliate of Elsevier, Inc., USA (2007).

23. Cheesbrough M. "District laboratory practices in Tropical countries". Volume 2 Part 2. Cambridge University Press, UK (2006).

24. Müller JD., et al. "Metrology for pH Measurements in Brackish Waters-Part 1: Extending Electrochemical pHT Measurements of TRIS Buffers to Salinities 5-20". Frontiers Marine Science 5.176 (2018):1-12.

25. Olatunji MK. "Assessment of water quality in Asa River (Nigeria) and its indigenous Clarias gariepinus Fish". International Journal of Environmental Research and Public Health 8 (2011): 4332-4352.
26. Azhar M., et al. "Soil and water quality parameters of Brackish water shrimp farms of Ratnagiri, Maharashtra". Asian Journal of Animal science 11. 2 (2016): 107-110.

27. United State Environmental Protection Agency (USEPA). "Ambient aquatic life water quality criteria for dissolved oxygen (saltwater): Cape Cod to Cape Hatteras" (2000).

28. Naubi I., et al. "Effectiveness of Water Quality Index for Monitoring Malaysian Water Quality Index". Polish Journal of Environmental Studies 25 (2016): 231.

29. Ayedun H., et al. "Assessment of groundwater contamination by toxic metals in Ifo, Southwestern Nigeria". Indian Journal of Science and Technology 4 (2011): 820.

30. Abowei JFN. "Salinity, dissolved oxygen, pH, and surface water temperature conditions in Nkoro River, Niger Delta, Nigeria". Advance Journal of Food Science and Technology 2.1(2010): 1621.

31. El-Amier YA., et al. "Assessment of the Physicochemical Characteristics of water and sediment in Rosetta Branch, Egypt". Journal of Water Resource and Protection 7 (2015): 1075-1086.

32. Rusydi AF. "Correlation between conductivity and total dissolved solid in various type of water: A review". IOP Conference Series: Earth and Environmental Science 118 (2018): 012019.

33. Omonona AO., et al. "Physicochemical and Microbiological Characteristics of water samples from Borgu sector of Kainji Lake National Park, Nigeria". International Journal of Environmental Research 7.2 (2019): 1-15.

34. Sivakumar S., et al. "Estimation of carbon stock in above Ground biomass, In: Muthupet Mangrove, Southeast coast of India". IJIAREC 2 (2011): 139-150.

35. Oladiji AT., et al. "Toxicological evaluation of surface water of Amilegbe River using rats". Niger Socical Exper Biochemical 16 (2004): 94-101.

36. Rajesh J., et al. "Environmental Impacts Assesssment of Brackish water Aquaculture Activity in Nagapattinam Region, South East coast of India". Journal of Environmental and Analytical Toxicology 6.3 (2016): 1-11.

37. Tarus JS., et al. "Analysis of Nitrates and Phosphates in drinking water samples collected from Tea growing Community, Nandi Hills, Kenya". Chemical Science International Journal 21.3 (2017): 1-8. 
38. Odjadjare EEO and Okoh AI. "Physicochemical quality of an urban municipal wastewater effluent and its impact on the receiving environment". Environmental Monitoring and Assessment 170 (2010): 394 .

39. Nyamangara J., et al. "Long term nitrate and phosphate loading river water in the Upper Manyane catchment, Zimbabwe". Water SA 39 (2013): 637.

40. Dube T., et al. "An assessment of the effect of industrial and sewage effluent on aquatic invertebrates: A case study of a Southern urban stream, Zimbabwe". Journal of Sustainable Development 3 (2010): 210-214.

41. Iwar RT., et al. "Temporal Variations in the Characteristics of Pre-treated Effluents from a Brewery in Makurdi MetropolisNigeria". American Journal of Environmental Protection 4. 2 (2016): 55-60.

42. Fadiran AO., et al. "A comparative study of the phosphate levels in some surface and ground water bodies of Swaziland". Bulletin of the Chemical Society of Ethiopia 22.2 (2008): 197-206.

43. Obire 0., et al. "The Bacteriological water quality of Elechi Creek in Port Harcourt". Nigeria Journal of Applied Science and Environmental Management 9. 1 (2005): 79-84.

44. Javed F., et al. "Effects of Seasonal Variations on Physicochemical Properties and Concentrations of Faecal coliform in RiverKabul". World Applied Sciences Journal 29. 1 (2014): $142-149$

45. Rochelle-Newall E., et al. "A short review of faecal indicator bacteria in tropical aquatic ecosystems: knowledge gaps and future directions". Front Microbiology 6 (2015): 308.

46. Ferrer N., et al. "What are the main factors influencing the presence of faecal bacteria pollution in groundwater systems in developing countries?" Journal of Contaminant Hydrology 228 (2020): 103556.

\section{Assets from publication with us}

- Prompt Acknowledgement after receiving the article

- Thorough Double blinded peer review

- Rapid Publication

- Issue of Publication Certificate

- High visibility of your Published work

Website: www.actascientific.com/

Submit Article: www.actascientific.com/submission.php

Email us: editor@actascientific.com

Contact us: +919182824667 